\title{
Motor and functional evaluation of patients with spastic paraplegia, optic atrophy, and neuropathy (SPOAN)
}

\author{
Zodja Graciani', Silvana Santos², Lucia Inês Macedo-Souza³, \\ Carlos Bandeira de Mello Monteiro ${ }^{4}$, Maria Isabel Veras ${ }^{5}$, \\ Simone Amorim ${ }^{6}$, Mayana Zatz ${ }^{7}$, Fernando Kok ${ }^{8}$
}

\begin{abstract}
Spastic paraplegia, optic atrophy, and neuropathy (SPOAN) is an autosomal recessive complicated form of hereditary spastic paraplegia, which is clinically defined by congenital optic atrophy, infancy-onset progressive spastic paraplegia and peripheral neuropathy. In this study, which included 61 individuals (age 5-72 years, 42 females) affected by SPOAN, a comprehensive motor and functional evaluation was performed, using modified Barthel index, modified Ashworth scale, hand grip strength measured with a hydraulic dynamometer and two hereditary spastic paraplegia scales. Modified Barthel index, which evaluate several functional aspects, was more sensitive to disclose disease progression than the spastic paraplegia scales. Spasticity showed a bimodal distribution, with both grades 1 (minimum) and 4 (maximum). Hand grip strength showed a moderate inverse correlation with age. Combination of early onset spastic paraplegia and progressive polyneuropathy make SPOAN disability overwhelming.

Key words: hereditary spastic paraplegia, peripheral nervous system disorder, optic atrophy, scales, psychomotor performance.
\end{abstract}

\section{Avaliação motora e funcional de pacientes com paraplegia espástica, atrofia óptica e neuropatia (SPOAN)}

\section{RESUMO}

A paraplegia espástica, atrofia óptica e neuropatia (SPOAN) é uma forma complicada de paraplegia espástica de herança autossômica recessiva, caracterizada por atrofia óptica congênita, paraplegia espástica progressiva de início na infância e neuropatia periférica. Este estudo avaliou o desempenho motor e funcional de 61 indivíduos com SPOAN (5 a 72 anos), por meio do índice de Barthel modificado, a escala modificada de Ashworth, da avaliação da força de preensão das mãos com dinamômetro hidráulico de Jamar e escalas de paraplegia espástica hereditária. O índice de Barthel modificado, que investiga aspectos funcionais, mostrou-se mais sensível para avaliar a progressão da doença do que as escalas de paraplegia espástica. A espasticidade apresentou distribuição bimodal, com o grau 1 (mínimo) e 4 (máximo). A força de preensão mostrou correlação inversa moderada

\section{Correspondence}

Fernando Kok

Serviço de Neurologia Infantil /

Departamento de Neurologia / FMUSP

Av. Dr. Enéas de C. Aguiar 255 / S 5011

05403-000 São Paulo SP - Brasil

E-mail: fernando.kok@fleury.com.br

\section{Support}

Conselho Nacional de Pesquisas (CNPq) and Fundação de Amparo à Pesquisa do Estado de São Paulo (FAPESP)

Received 3 July 2009

Accepted 8 September 2009 com a idade. A combinação de paraplegia espástica de início precoce com polineuropatia progressiva faz da SPOAN uma condição incapacitante.

Palavras-chave: paraplegia espástica hereditária, doença do sistema nervoso periférico, atrofia óptica, escalas, performance psicomotora.

'Physiotherapist, Assistant Professor of Physiotherapy of Santo Amaro University, MS Student of Postgraduate Program in Neurology, Department of Neurology, University of São Paulo School of Medicine (FMUSP), São Paulo SP, Brazil; 'Biologist, PhD, Assistant Professor, Biology Department, Paraíba State University, Campina Grande PB, Brazil; ${ }^{3}$ Biologist, PhD, Posdoctoral fellow of Center for Human Genome Research, Biosciences Institute, University of São Paulo (USP), São Paulo SP, Brazil; ${ }^{4}$ Physiotherapist, PhD, Assistant Professor of Physiotherapy, Metropolitanas Unidas University, São Paulo SP, Brazil; ${ }^{5}$ Physicist, PhD Student of Postgraduate Program in Physics, Physics Institute, USP; ${ }^{6}$ Medical Doctor, PhD Student of Postgraduate Program in Neurology, Department of Neurology, FMUSP; ${ }^{7}$ Biologist, PhD, Professor of Genetics, Center for Human Genome Research, Biosciences Institute, USP, ${ }^{8}$ Medical Doctor, PhD, Associate Professor, Postgraduate Program in Neurology, Department of Neurology, FMUSP. 
Spastic paraplegia, optic atrophy and neuropathy (SPOAN) (OMIM \# 609641) is a neurodegenerative disorder recently described in Brazil by our group ${ }^{1,2}$, in individuals from Rio Grande do Norte State. This condition is characterized by: (a) congenital and non progressive optic atrophy; (b) progressive spastic paraplegia, with onset early in life, leading to loss of autonomous ambulation before adolescence; (c) axonal neuropathy, with clinical onset after the first decade of life and causing progressive loss of function of upper limbs; (d) startle response with unexpected sounds; (e) dysarthria; and (f) joint retractions and spine deformities ${ }^{1,2}$.

Up to now, we are aware of 71 patients with SPOAN, belonging to 44 nuclear families, 41 of each are known to be consanguineous. Most of them are living in SW Rio Grande do Norte state, concentrated in Serrinha dos Pintos and São Miguel municipalities ${ }^{2}$. It is estimated that 1 in every 170 inhabitants of Serrinha dos Pintos (population in 2000: 4,250) is affected by SPOAN. SPOAN is linked to chromosome 11q13, but its responsible gene remains unknown. No other form of hereditary spastic paraplegia, optic atrophy or neuropathy maps to the same chromosomal region of SPOAN ${ }^{1,2}$.

The purpose of this study is to perform a quantitative motor and functional evaluation in a series of patients with SPOAN, in order to better understand disease progression and overall performance. As most of those individuals are living in small communities, with scarce healthcare resources, as a rule they previously had no access to any kind of structured rehabilitation program.

\section{METHOD \\ Patients}

Sixty-one individuals (42 females) with clinical diagnosis of SPOAN and in which genetic study demonstrates linkage to chromosome 11q13 participate of this study. Age at ascertainment ranged from 5 to 72 years [mean age of $34( \pm 13)$ years]. Clinical data of those patients have already been presented elsewhere ${ }^{1,2}$. Information used in this study was collected through direct observation and with patients interview, usually conducted close to their hometown.

This study was approved by Biosciences Institute Ethics Committee and an informed consent for participation was obtained from patients or their caregivers.

\section{Procedures}

The following scales and quantitative instruments were used in this study:

(1) The Spastic Paraplegia Rating Scale (SPRS), which evaluate 13 variables graded from 0 (normal) to 4 (severe). The maximum obtainable score is $52^{3}$.

(2) The Functional Hereditary Spastic Paraplegia Rat- ing Scale (FHSPS), which is a semi-quantitative instrument to measure gait dysfunction level. It is graded from 0 (normal) to 5 (maximum) 4 .

(3) The Modified Barthel Index (MBI), to evaluate functional performance in 10 functional categories (personal hygiene, bath, feeding, toilet, stairs climbing, dressing, gait, transfer ability, bowel and bladder control). Dependence level was ranked according to achieved performance in total (0-24 points), severe (25-50), average (5175), and minimum (76-99) $)^{5,6}$.

(4) Sural triceps, quadriceps and hip adductors spasticity was evaluated using Modified Ashworth Scale $(\mathrm{MAS})^{7-9}$.

(5) Left and right hand grip strength was measured using a Jamar hydraulic dinamometer (Asimow Eng., Trenton, Canada), following established standards. Mean value of three attempts with one minute interval was calculated for each hand. Reference values were supplied by the manufacturer ${ }^{10,11}$.

\section{RESULTS}

For data analysis, sample was divided according to age in five groups: under 20 years, 20 to 29 years ([20, 30[), 30 to 39 years ([30, 40[), 40 to 49 years $([40,50[)$ and above 50 years.

Table. Mean score, standard deviation, maximum and minimum values obtained in the five age groups with the implementation of Spastic Paraplegia Rating Scale.

\begin{tabular}{cccccc}
\hline Age groups & N & Mean & SD & Min & Max \\
\hline$<20$ & 3 & 35 & 3 & 33 & 38 \\
{$[20,30[$} & 15 & 41 & 4 & 35 & 48 \\
{$[30,40[$} & 16 & 41 & 5 & 34 & 50 \\
{$[40,50[$} & 16 & 43 & 4 & 38 & 51 \\
$>50$ & 10 & 41 & 4 & 37 & 51 \\
\hline
\end{tabular}

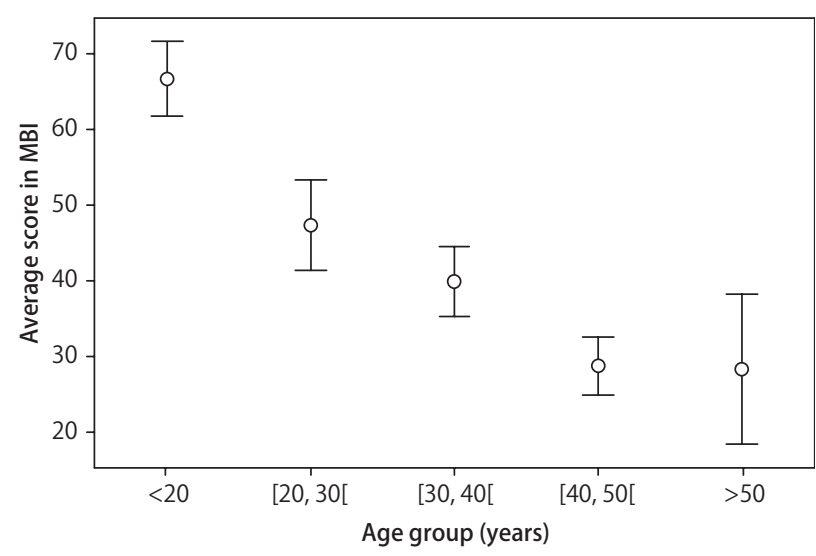

Fig 1. Mean score obtained in five age groups in the Modified Barthel Index. 


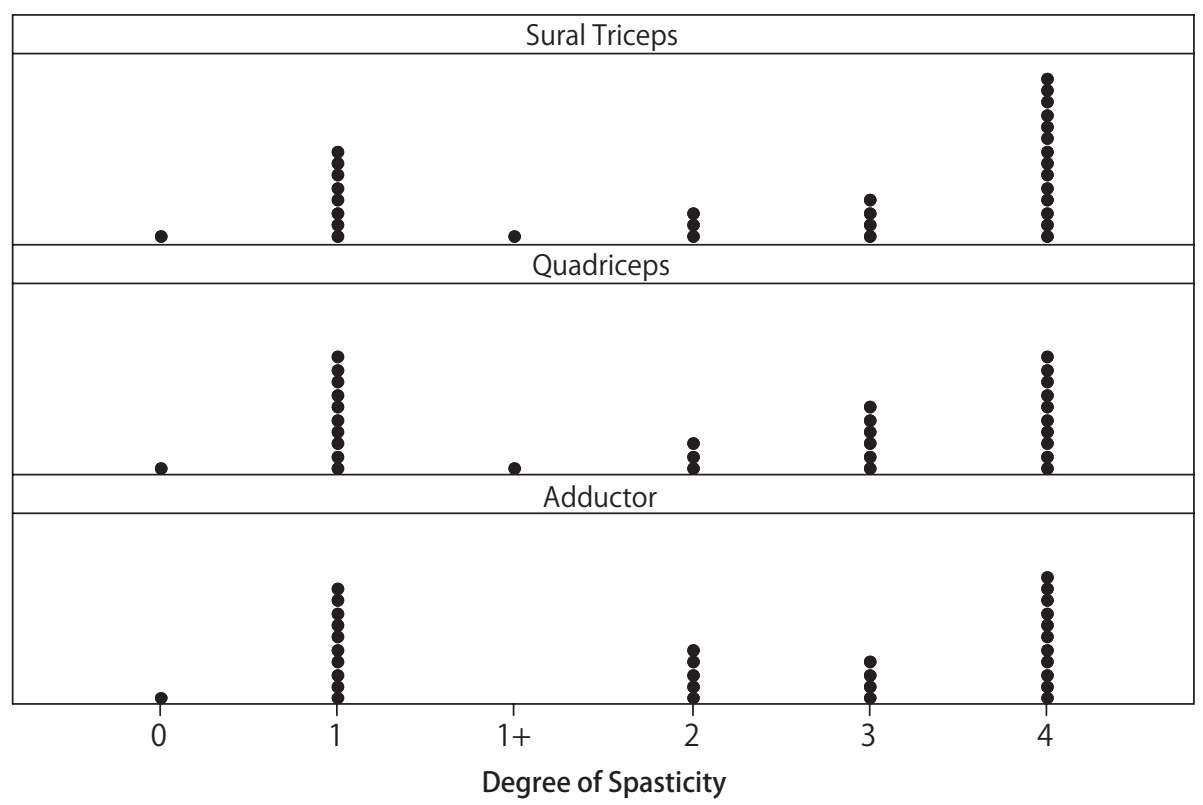

Fig 2. Dispersion graphic showing spasticity degree according to Modified Ashworth Scale of muscles sural triceps, quadriceps and hip adductor. Each symbol corresponds to up to two observations. It can be noted that patients are concentrated in grade 1 (minimum) and 4 (maximum).

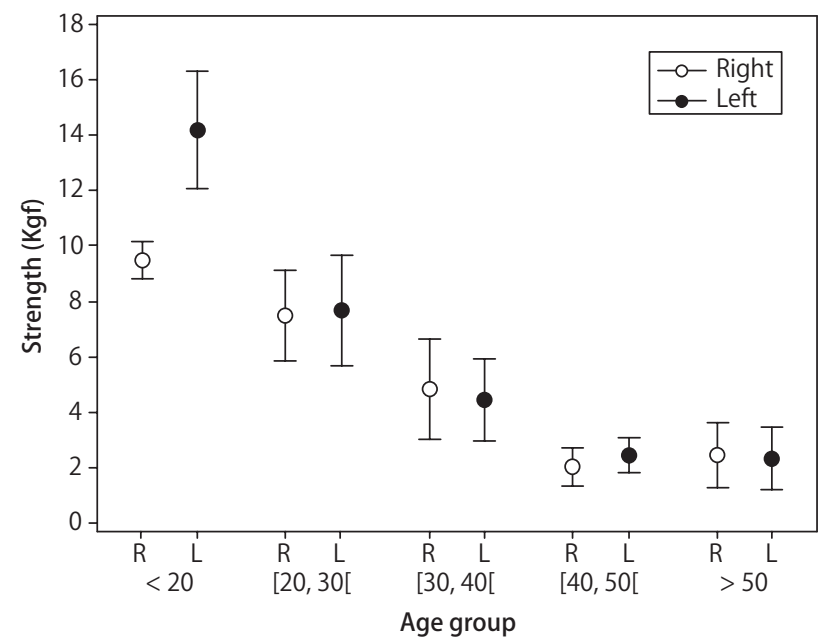

Fig 3. Mean values in Kgf for the hands grip strength according to age group.

SPRS was determined in 60 individuals (the 5 -yearold subject was not included), and an average score of 40.7 points $( \pm 5.5)$ was obtained. Mean scores in five age ranges is presented in Table. Lowest individually achieved score was of 27 and highest of 52 points; $60 \%$ of individuals had score above 40 points. Mean score was not significantly different across 5 different ranges of age, and remained stable after 20 years of age, with average of 41 to 43 points. Therefore no correlation was seen between SPRS score and age.

Applying FHSPS to 61 individuals with SPOAN, it was determined that 44 (72.1\%) had level 5, or maximum, of dysfunction, which is characterized by severe loss of gait and wheelchair use for more than 50\% of time. 14 (22.9\%) were at level 4, one (1.6\%) at level 3 and one (1.6\%) at level 2 of dysfunction.

BMI, used for functional assessment, disclosed maximum level of dependency in 28 individuals (45.9\%), total dependency in 16 (26.2\%), average in 14 (22.9\%) and minimum in 2 (3.3\%) subjects. Pearson linear correlation coefficient demonstrate a moderate correlation between scores and age, demonstrating that individual score decreases with age, which means that a functional deterioration occurs in SPOAN (Fig 1).

According to MAS, lower limbs spasticity had a bimodal distribution, with subjects concentration in levels 1 (minimum) and 4 (maximum), as can be appreciated in Figure 2.

Hand grip measurement showed that strength decreases with age and that right hand grip was not different form left one (Fig 3).

\section{DISCUSSION}

SPOAN is a complicated form of HSP which leads to an early and severe handicap ${ }^{1,2}$. Nevertheless, SPRS and FHSPS, the two available scales for HSP evaluation, were not useful indicators of disease progression, as most patients achieve early in life high scores in both scales. In this sense, MBI was more sensitive to appreciate disease progression, as it evaluates other functions, some of them highly dependable of upper limbs functionality ${ }^{6,12}$. 
As in SPOAN occurs a combination of upper and lower neuron compromise, which progress at different rates and have opposite effect on tonus, disease pattern can change overtime. Nevertheless, independently of age, in some individuals symptoms secondary to lower motoneurons compromise prevail and in other subjects, upper motoneuron clinical manifestations are dominant. Bimodal distribution of lower limbs tone, as seen with MAS, is probably secondary to this mutually opposed effect of spinal cord and motor neuropathy on tonus.

Hand grip evaluation allows quantification of age related strength deterioration, secondary to relentless progression of sensory and motor axonal neuropathy. Loss of hands strength correlates positively with neuropathy progression.

This study did not evaluate visual function, which might be contributory to dependency. Nevertheless, there is no evidence that in SPOAN there is a deterioration of visual function and therefore it is not expected to have a functional change. For lack of an adequate instrument, it was not analyzed the influence on overall performance of spine and joints deformities, present in variable degree in most patients.

In summary, this investigation allows quantify the motor and functional performance of 61 individuals diagnosed with SPOAN and suggests that this complicated form of HSP has a lifelong progression. Specific scales for HSP did not appreciate disease progression, as functional deterioration of lower limbs is an early event and achieves a maximum before 20 years of age. By the other hand, functional scales as BMI, with a more comprehensive inventory of evaluated items, perform better for investigation of disease progression and overall individual performance.

ACKNOWLEDGMENTS - We are grateful to all patients and their families for their unrestricted support. We are indebt with Serrinha dos Pintos and São Miguel municipalities as well as with Rio Grande do Norte state health authorities, for their support.

\section{REFERENCES}

1. Macedo-Souza LI, Kok F, Santos S, et al. Spastic paraplegia, optic atrophy, and neuropathy is linked to chromosome 11q13. Ann Neurol 2005;57:730-737.

2. Macedo-Souza LI, Kok F, Santos S, et al. Spastic paraplegia, optic atrophy, and neuropathy: new observations, locus refinement, and exclusion of candidate genes. Ann Hum Genet 2009;73:382-387.

3. Schule R, Holland-Letz T, Klimpe S, et al. The Spastic Paraplegia Rating Scale (SPRS): a reliable and valid measure of disease severity. Neurology 2006;67:430-434.

4. Hedera P, DiMauro S, Bonilla E, Wald J, Eldevik OP, Fink, JK. Phenotypic analysis of autosomal dominant hereditary spastic paraplegia linked to chromosome 8q. Neurology 1999;53:44-50.

5. Shah S, Vanclay F, Cooper B. Improving the sensitivity of the Barthel Index for stroke rehabilitation. J Clin Epidemiol 1989;42:703-709.

6. Granger CV, Hamilton BB, Gresham GE, Kramer AA. The Stroke Rehabilitation Outcome Study: part II. Relative merits of the total Barthel Index score and a form-item subscore in predicting patients outcomes. Arch Phys Med Rehabil 1989;70:100-103.

7. Bohannon RW, Smith MB. Interrater reliability of a modified Ashworth scale of muscle spasticity. Phys Ther 1987;67:206-207.

8. Platz T, Eickof C, Nyens G, Vuandes P. Clinical scales for the assessment of spasticity, associated phenomena, and function: a systematic review of the literature. Disabil Rehabil 2005;27:7-18.

9. Thompson AJ, Jarrett L, Lockley L, Marsden J, Stevenson VL. Clinical management of spasticity. J Neurol Neurosurg Psychiatry 2005;76:459-463.

10. Caporrino FA, Faloppa F, Santos JBG, Réssio FHC, Nakachima LR, Segre NG. Estudo populacional da força de preensão palmar com dinamômetro de Jamar. Rev Bras Ortop 1998;33:150-154.

11. Schlüssel MM, Anjos LA, Vasconcelos MTL, Kac G. Reference values of handgrip dynamometry of health adults: a population-based study. Clin Nutr 2008;27:601-607

12. Cohen ME, Marino RJ. The tools of disability outcomes research functional status measures. Arch Phys Med Rehabil 2000;81(Suppl):S21-29. 